DOI: 10.20472/BMC.2018.008.002

\author{
ADRIANA CSIKÓSOVÁ \\ Technical university of Košice, Slovak Republic \\ KATARÍNA ČULKOVÁ \\ Technical university of Košice, Slovak Republic \\ MÁRIA JANOŠKOVÁ \\ Technical university of Košice, Slovak Republic
}

\title{
WORK PRODUCTIVITY AND EMPLOYMENT IN CHOSEN EU COUNTRIES
}

\begin{abstract}
:
Work productivity presents one of the factors, influencing economic growth of the country. On the other hand work productivity is also influenced by various factors. There are raising differences in work productivity among individual countries. Human capital can influence work productivity through employment, which can be analyzed from various points of view. The goal of the paper is therefore to identify work productivity in EU-28 with emphasize to V4. The main analysis had been done by available database in European system of national and regional accounts and according introduced statistic classification of economic activities from European Parliament Decree. The main indexes of work productivity had been calculated according obtained data with using of descriptive statistics. According mentioned statistics we found which country is the best and which is the worst from the view of analyzed indexes. The last part of the paper presents following up of reason of determined state with setting of possible solutions.
\end{abstract}

\section{Keywords:}

Economic effectiveness, Employment, Performance, Productivity, Work quality.

JEL Classification: E24, J49 


\section{Introduction}

There is number of factors influencing economic growth as an indicator of economic performance of the country. Work productivity presents one of these factors, when number of authors considers work productivity as the most important factor. Work productivity is influenced also by other factors, for example at the level of small and medium enterprises (SMEs), at the regional level of at the level of states economies and integrated countries. Differences and space for work productivity increasing at various levels are still visible.

Productivity is one of the most important and most significant factors of the economy effectiveness. Generally, productivity can be seen as efficiency of machines, people, sources or system. Two most important variants of productivity present total productivity and work productivity of the single factors. Productivity expresses rate between input and output. Natural sources, human sources, capital creation and technological process influence growth of the economical productivity. Number of economists trusts the work quality; abilities and knowledge are most important part of economic growth. Number of factors influence single work productivity, for example human capital, level of education and qualification, technological level of equipment, technological changes and innovation, geographical and natural conditions or skills of the companies, management, etc. According mentioned specifications of any country of area of economy there are raising differences in work productivity not only among individual parts of the country, but also among countries themselves. Human capital can influence work productivity through employment, which can be analyzed from various points of view: age category of employed, achieved education level, gender, gender equality, including also righteous behavior with both genders at the job market, which means equivalence from various points of view: legal view, from the view of advantages, possibilities or responsibilities of men and women.

Presented contribution analyzes and identifies work productivity in EU-28 and V4 with aim to find the development trend of work productivity in time, in individual sectors, as well as in chosen countries.

\section{Present state of problem solving}

Area of productivity is studied by number of authors from different views. For example, Harris and Moffat (2016) made the study in Great Britain, when recorded big decrease of work productivity mainly in production and services after financial crisis. Regional differences in work productivity had been studied by Oosterhaven and Broersma (2007), when regional difference in work productivity depended on sector structure, cluster economies and defined remaining regional part. Dhingra and Morrow (2017) draw attention to the differences in productivity within the industries, stating productivity differences introduce two new margins for allocation inefficiency. Increased competition 
from market expansion takes the economy closer to the socially efficient allocation of resources.

Gust and Marquez (2004) saw productivity from the view of its growth, determined IT is credits with the highest growth in productivity, especially in USA, while many other industrial countries have not experienced a pickup in productivity growth. According the study burdensome regulatory environments and, in particular, regulations affecting labor market practices have impeded the adoption of information technologies and have slowed productivity growth in a number of industrial countries.

Arnold and Hussinger (2005) examined the causal relationship between productivity and exporting in manufacturing, analyzing whether the presence in international markets enables firms to achieve further productivity improvements. High-productivity firms selfselect themselves into export markets, while exporting itself does not play a significant role for the productivity of the firms.

Bernard et al. (2003) examined the impact of globalization on productivity, plant entry and exit, and labor turnover in manufacturing. Authors determined factors, influencing productivity, as follows: productivity dispersion, higher productivity among exporters, the small fraction who export and the small fraction earned from exports among exporting plants, and the size advantage of exporters. From this factors there is obvious productivity efficiency depends on the period of life cycle and orientation of the company, for example Baek and Neymotin (2016) studied productivity of startup and exporting firms, found a small firm's exports are positively related to their level of productive efficiency.

Orientation of the company from the view of exporters and non-exporters of the products studied also Aw and Hwang (1995) to distinguish the productivity differences. According the study there are significant differences in productivity levels between exporters and non-exporters, depending on the product specification.

Productivity differences between exporting and non-exporting firms examined also Delgado et al. (2002), indicating clearly higher levels of productivity for exporting firms than for non-exporting firms. Authors found evidence supporting the self-selection of more productive firms in the export market.

Productivity growth had been studied also in relation with employment and wages (Asaleye et al., 2017). Authors investigated the impact of the growth on labor market performance, showed that the output growth does not translate into employment gains both in the short and long-run while the influence of wages is not statistically significant. The implication is that the wages do not adjust to reflect the cost of living both in the short and long-run. Onkelinx et al. (2016) find that firm-level investments in employee human capital are critical for the labor productivity and internationalization in fast internationalizes, but not for those SMEs firms that internationalize more slowly. 
Petrashchak et al. (2017) studied factors, influencing behavior of the employees towards productivity, which are: employment stability; financial rewards; comfortable working environment; favorable working conditions and professional development. The authors found out also mistakes to the motivational stimuli as for example: exaggeration of the influence of such factors as discipline control, professional development on the job activity evaluation and the underestimation of such factors as job stability, pay rate increase (Hakelová et al., 2013).

Employment trend is closely connected with value added growth (Donnellan and Hanrahan, 2017), when substantially different economic developments are evident in the primary and processing sectors (Kolveková \& Palaščáková, 2017). The agricultural and food processing sectors remained more important in the economies of the EU Member States of Central and Eastern Europe than in those of Western Europe.

In the context of productivity and employment Kornelakis et al. (2017) studied if firms with employment relations institutions have been less able to improve productivity during the crisis, stated there is any strong evidence that employment relations institutions are negatively associated with productivity increases. Instead certain high performance work practices are positively and significantly associated with productivity increases across EU-15 and in particular institutional contexts. During the past times the chain of three links organizational strategy - human resources practices - organizational performance has been deeply analyzed. However, the mediator role of organizational structure in the first link of this chain remains relatively uninvestigated. Camps and Luna-Arocas (2009) analyzed a model of relationships among organizational strategy, organizational structure, human resources practices, and organizational performance. Organizations with differentiation strategies are more likely to implement high involvement work practices.

\section{Methodology}

The analysis had been orientated to the identification of work productivity in EU-28 and V4. All data had been provided from database EUROSTAT, based on European system of national and regional accounts ESA 2010, according which productivity is defined as gross value added per hour worked. Gross value added (GVA) is defined by ESA 2010 as value of output, expressed in basic prices, decreased by intermediate consumption, evaluated in purchase prices. GVA is used in common prices in mil. EUR for all NACE activities. According European Parliament Decree in 2006 there is introduced statistic classification of economic activities NACE Revision 2. During the analysis one of the correspondent program ESA of activities classification had been used, mainly $A^{*} 10$, dividing activities according the sectors to ten NACE sections Rev. 2 according EUROSTAT. The sectors are as follows: 
1. A- agriculture, forestry and fishery.

2. $B, C, D$ a $E(B-E)$ - mining and exploitation; processing industry; supplying of electric energy, gas, steam and cold air; water supplying; cleaning and drainage of waste water, wastes and services, connected with waste disposal.

3. F-construction.

4. G, H a I (G-I) - whole sale and retail; repair of car vehicles and motorcycles; transport and stocking; accommodation and catering services.

5. $J$-information and communication.

6. K- financial and insurance activities.

7. $L-$ activities in area of real estate.

8. $M$ a $N(M-N)$ - expert, scientific and technical activities; administration and subsidiary services.

9. $O, P$ a $Q(O-Q)$ - public administration and defense; obligatory social provision; education; health care and social help.

10.R, S, $T$ a $U(R-U)$ - art, entertainment and recreation; other activities in area of services; household's activities as employers; not differentiated activities of households.

Work productivity is calculated as a rate between GVA and number of hours worked by employed persons in given sector.

$$
\text { Work Productivity } \frac{\text { GVA (fixed prices in mil.EUR }) * 100}{\text { hours worked (th.hours })}
$$

As an input index for hours worked in thousand hours we considered concept of total employment for all NACE activities according $A^{*} 10$ structure, expressed in mil. hours worked by employed persons in given sector.

Due to the better interpretation of work productivity development in EU-28 we calculated growth index for all years in chosen time period as follows:

$$
\text { Work Productivity } \frac{\text { GVA (fixed prices in mil.EUR }) * 100}{\text { hours worked (th.hours })}
$$

Index employment speak about number of employed persons in analyzed area or it can be expressed as percentage change of employment on total number of active inhabitants, including also unemployed, but actively looking for a job (Lisý, 2016).

$$
\text { Work Productivity } \frac{\text { GVA (fixed prices in mil.EUR }) * 100}{\text { hours worked (th.hours })}
$$


According EUROSTAT we considered to total employment also persons over 15 years that make any job, persons absent in working process due to the illness, maternity and parental leave, vacation, increasing of qualification, etc. measure of employment can be expressed as total measure, or as partial measure, connected with chosen segment of job market (Muller et al., 2017). For example, at gross measure of economic activity we speak about number of persons in age 15-64 years as percentage of total population, at net measure of economic activity we speak about percentage of age group 15-64 years from total number of inhabitants mainly of this age group. Index economic activity is constructing for specific age groups, for example: economic activity of young people between 15-24 years, economically active inhabitants in between 25-64 years with assumption of yet finished education. Since there is possible to search measure of employment, mainly economic activity of inhabitants from various points of view, our analysis had been done by gender. EUROSTAT expresses measure of men and women activity individually as percentage of employed men and women population, not as a rate on total population.

Due to the analysis of employment we used indexes of descriptive statistics (Tkáč, 2001), by which we described development of the indexes: arithmetic average, average deviation, dispersion, standard deviation, variation range, variation coefficient.

During the analysis process we analyzed first of all gender differences at the job market at the level of the country, mainly according nomenclature of local statistic units at the level NUTS1. Further we orientated to age group 15-64 years, which means whole productive period of the person. Time horizon of the analysis is 2005-2016, while analysis of the information was made according annual base, using information from database Eurostat.

\section{$4 \quad$ Results}

\subsection{Analysis of work productivity in EU-28}

Work productivity in ten sectors of the economy according $A^{*} 10$ structure in EU-28 is calculated according the stated methodology during 2005-2016, all data available from database Eurostat (see Figure 1). 


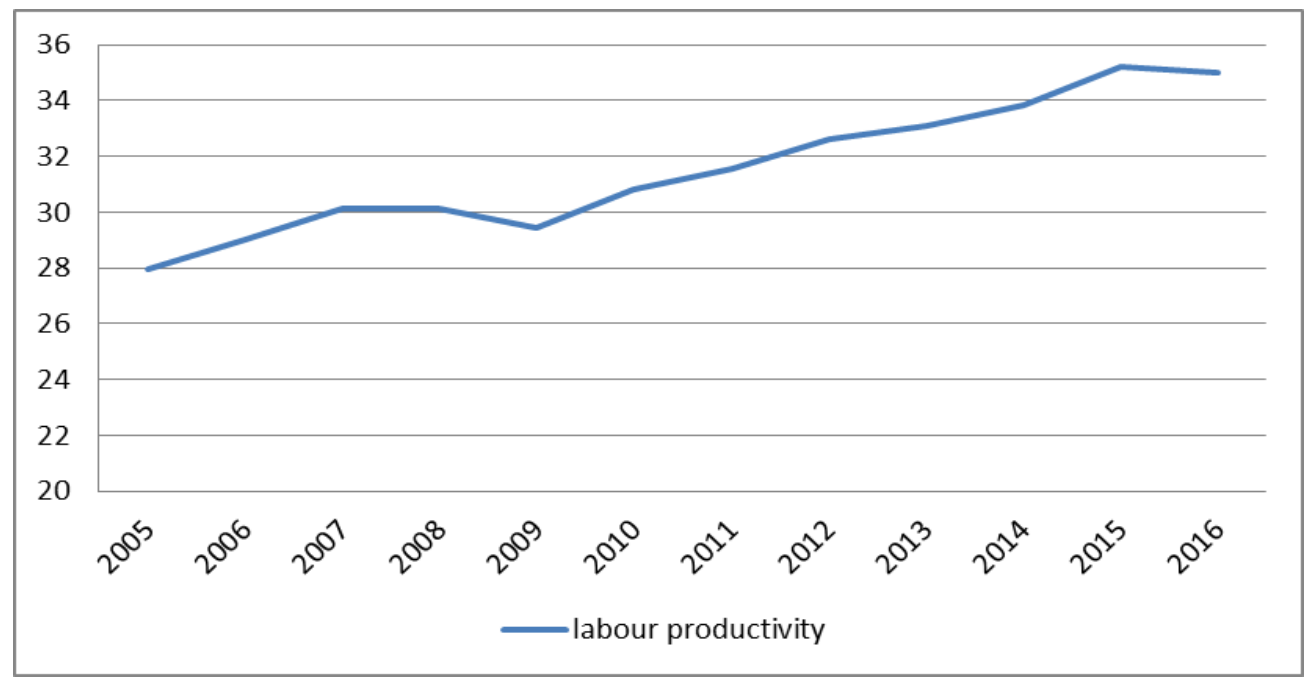

Figure 1: Development of work productivity for all NACE activities in EU-28 in EUR per hour worked

Source: own processing according EUROSTAT

Development of work productivity during the analyzed period has an increasing trend. Work productivity in EU-28 for all NACE activities increased from 27.95 EUR to 35.01 EUR per hour worked. The only one recorded decreasing of work productivity is visible in 2009 (see Table 1) as a consequence of global financial crisis that influenced slowdown or decrease of economic growth as well as work productivity. Except of mentioned decrease stagnation is visible also in 2007, 2008 and 2016.

Table 1: Coefficients of work productivity growth in EU countries during 2005-2016

\begin{tabular}{|c|c|c|c|c|c|}
\hline & EU-28 & $\begin{array}{c}\text { Growth } \\
\text { coefficient }\end{array}$ & & EU-28 & $\begin{array}{c}\text { Growth } \\
\text { coefficient }\end{array}$ \\
\hline $\mathbf{2 0 0 5}$ & 27.95 & $X$ & $\mathbf{2 0 1 1}$ & 31.57 & 1.02 \\
\hline $\mathbf{2 0 0 6}$ & 28.99 & 1.04 & $\mathbf{2 0 1 2}$ & 32.62 & 1.03 \\
\hline $\mathbf{2 0 0 7}$ & 30.11 & 1.04 & $\mathbf{2 0 1 3}$ & 33.11 & 1.02 \\
\hline $\mathbf{2 0 0 8}$ & 30.15 & 1.00 & $\mathbf{2 0 1 4}$ & 33.83 & 1.02 \\
\hline $\mathbf{2 0 0 9}$ & 29.42 & 0.98 & $\mathbf{2 0 1 5}$ & 35.19 & 1.04 \\
\hline $\mathbf{2 0 1 0}$ & 30.82 & 1.05 & $\mathbf{2 0 1 6}$ & 35.02 & 1.00 \\
\hline
\end{tabular}

Source: own processing according database Eurostat

Work productivity analysis in individual sectors of the economy according NACE classification for all EU-28 countries during analyzed period recorded highest and lowest work productivity in the same sectors according following ranking:

Ranking of sections according highest work productivity consists of three strongest sections from the view of productivity:

1. L-section with average value 330.75 EUR per hour worked.

2. K-section with average value 62.52 EUR per hour worked.

3. J-section with average value 54.17 EUR per hour worked. 
On the other hand, ranking of sections according lowest work productivity in 2005-2016 in all EU-28 countries is as follows:

1. The lowest average work productivity recorded in A-section, mainly 8.47 EUR per hour worked.

2. A little better average work productivity is recorded in $\mathrm{R}-U$ sections with average value 20.70 EUR per hour worked.

3. F-section with average value 23.44 EUR per hour worked.

The results show the worst work productivity is achieved in economic activities that are based on physical human sources and generally achieve low wage evaluation of the employees, which could be also one of the reasons for low productivity. On the other hand, sectors with high work productivity, mainly financial and information sector, dispose with high technological equipment that help the workers in production process and wages are in these sectors generally higher. Mainly those two aspects can be main components for achievement of high work productivity.

\subsection{Analysis of work productivity in V4 countries}

Except of single work productivity analysis in all EU-28 countries and sectors identification with lowest and highest work productivity in 2005-2016 we orientated analysis further to the analysis of work productivity in V4 countries, since those countries have not only common historic experiences with communism, but also mentality, cultural background, traditions, as well as strategic economic interest and complex reforms and transition to the market economy, which is unique in the Europe. Following Figure 2 illustrates development of work productivity in Czech Republic, Hungary, Poland and Slovakia in all NACE activities during 2005-2016. During the period work productivity increased from 7.4 EUR to 18.06 EUR per hour worked. Also considerable change was in 2009 due to the financial crisis in three from four analyzed economies. Only Slovakia did not record considerable decrease, in comparing with other countries. Development and values of work productivity for all NACE activities were very close in Slovakia and Czech Republic, and Poland and Hungary recorded also very close values. 


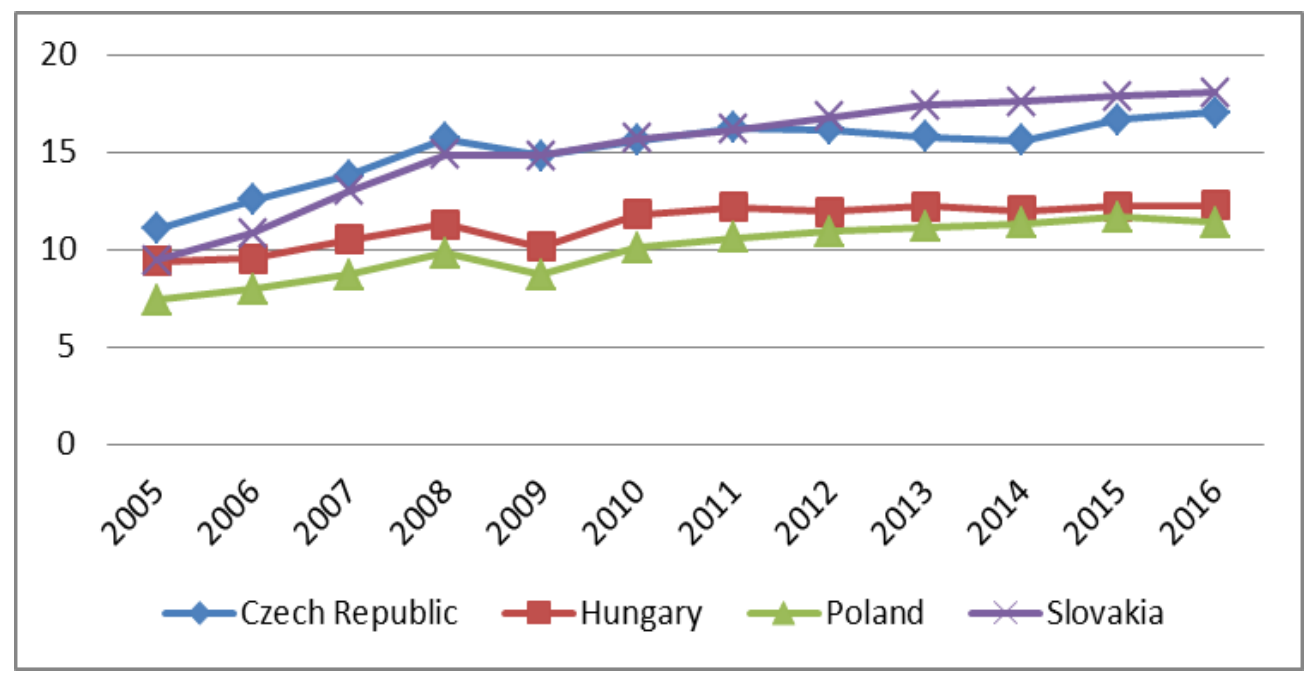

Figure 2. Development of work productivity for all NACE activities in V4 during 2005-2016 in EUR per hour worked

Source: own processing according database Eurostat

Growth index had been calculated for V4 countries, illustrated by Table 2, which proves decrease of work productivity in 2009 for all four countries, but the highest decrease $11.55 \%$ was recorded in Poland and the lowest decrease $-0,004 \%$ had been recorded in Slovakia. Next decrease was recorded in 2009, 2012-2014 in Czech Republic, in 2009, 2012 and 2014 in Hungary and Poland in 2009 and 2016. Slovakia achieved expects in 2009 the highest work productivity growth in 2007 , mainly by $19.84 \%$. According results of the work productivity analysis of NACE activities according $A^{\star} 10$ structure for EU countries we identified three sectors with the best and three sectors with the worst work productivity in 2005-2016.

Table 2: Work productivity in V4 countries in 2005-2016 in EUR per hour worked

\begin{tabular}{|c|c|c|c|c|c|c|c|c|}
\hline Year & $\begin{array}{c}\text { Czech } \\
\text { Republic }\end{array}$ & Trend & Hungary & Trend & Poland & Trend & Slovakia & Trend \\
\hline $\mathbf{2 0 0 5}$ & 11.08 & $\mathrm{X}$ & 9.40 & $\mathrm{X}$ & 7.40 & $\mathrm{X}$ & 9.45 & $\mathrm{X}$ \\
\hline $\mathbf{2 0 0 6}$ & 12.55 & 1.13 & 9.54 & 1.01 & 7.98 & 1.08 & 10.84 & 1.15 \\
\hline $\mathbf{2 0 0 7}$ & 13.78 & 1.10 & 10.52 & 1.10 & 8.70 & 1.09 & 13.00 & 1.20 \\
\hline $\mathbf{2 0 0 8}$ & 15.71 & 1.14 & 11.30 & 1.07 & 9.83 & 1.13 & 14.85 & 1.14 \\
\hline $\mathbf{2 0 0 9}$ & 14.79 & $\mathbf{0 . 9 4}$ & 10.11 & $\mathbf{0 . 9 0}$ & 8.69 & $\mathbf{0 . 8 8}$ & 14.80 & 1.00 \\
\hline $\mathbf{2 0 1 0}$ & 15.57 & 1.05 & 11.79 & 1.17 & 10.11 & 1.16 & 15.67 & 1.06 \\
\hline $\mathbf{2 0 1 1}$ & 16.26 & 1.04 & 12.19 & 1.03 & 10.58 & 1.05 & 16.16 & 1.03 \\
\hline $\mathbf{2 0 1 2}$ & 16.13 & $\mathbf{0 . 9 9}$ & 11.96 & $\mathbf{0 . 9 8}$ & 10.94 & 1.03 & 16.80 & 1.04 \\
\hline $\mathbf{2 0 1 3}$ & 15.76 & $\mathbf{0 . 9 8}$ & 12.20 & 1.02 & 11.14 & 1.02 & 17.39 & 1.03 \\
\hline $\mathbf{2 0 1 4}$ & 15.60 & $\mathbf{0 . 9 9}$ & 11.98 & $\mathbf{0 . 9 8}$ & 11.35 & 1.02 & 17.58 & 1.01 \\
\hline $\mathbf{2 0 1 5}$ & 16.66 & 1.07 & 12.22 & 1.02 & 11.66 & 1.03 & 17.85 & 1.02 \\
\hline $\mathbf{2 0 1 6}$ & 17.01 & 1.02 & 12.24 & 1.00 & 11.40 & $\mathbf{0 . 9 8}$ & 18.06 & 1.01 \\
\hline
\end{tabular}

Source: own processing according database Eurostat 
Due to the detail analysis of V4 countries we selected three concrete years: 2005 - year after common entrance to EU; 2009 - year of most considerable influence of global financial crisis to number of countries from the view work productivity development; the last year 2014 was selected due to the data availability for single sections. Comparison is given by Table 3 . The highest work productivity was in these three analyzed years achieved in V4 countries in the same three sectors $-\mathrm{L}, \mathrm{K}$ and $\mathrm{J}$, which presents the same results as in analysis of EU-28 countries. On the other hand, from the view of low work productivity these sectors had been different in V4 compared with EU-28. Hungary achieved low work productivity in G-I sections, Poland in O-Q sections and Slovakia had low work productivity in M-N and G-I sections. Only Czech Republic achieved totally equal results of sectors ranking according work productivity at three lowest positions, therefore Czech Republic has the similar development trend of work productivity as average values in EU-28.

Table 3: Three sections with highest and three sections with lowest work productivity in V4 in 2005, 2009 and 2014 in EUR per hour worked

\begin{tabular}{|l|l|l|l|}
\hline \multicolumn{1}{|c|}{2005} & \multicolumn{1}{c|}{2009} & \multicolumn{1}{c|}{2014} \\
\hline Czech Republic & L, J, K/R-U, F, A & L, J, K/R-U, F, A & L, K, J/A, F, R-U \\
\hline Hungary & L, J, K/R-U, G-I, A & L, J, K/G-I, F, A & L, K, J/A,R, U, F \\
\hline Poland & L, J, K/R-U, O-Q, A & L, J, K/R-U, O-Q, A & L, J, K/O-Q, R-U, A \\
\hline Slovakia & L, K, J/A, M-N, O-Q & L, K, J/M-N, O-Q, G-I & L, K, J/G-I, M-N, O-Q \\
\hline
\end{tabular}

Source: own processing according database Eurostat

Due to the comparing of work productivity in Hungary and Poland we analyzed two chosen sectors $-L-$ activities in area of real estate, where average value of work productivity during the whole period 2005-2016 was the highest, and sector A agriculture, forestry and fishery, in which average value work productivity was on the other hand the lowest in both Hungary and Poland.

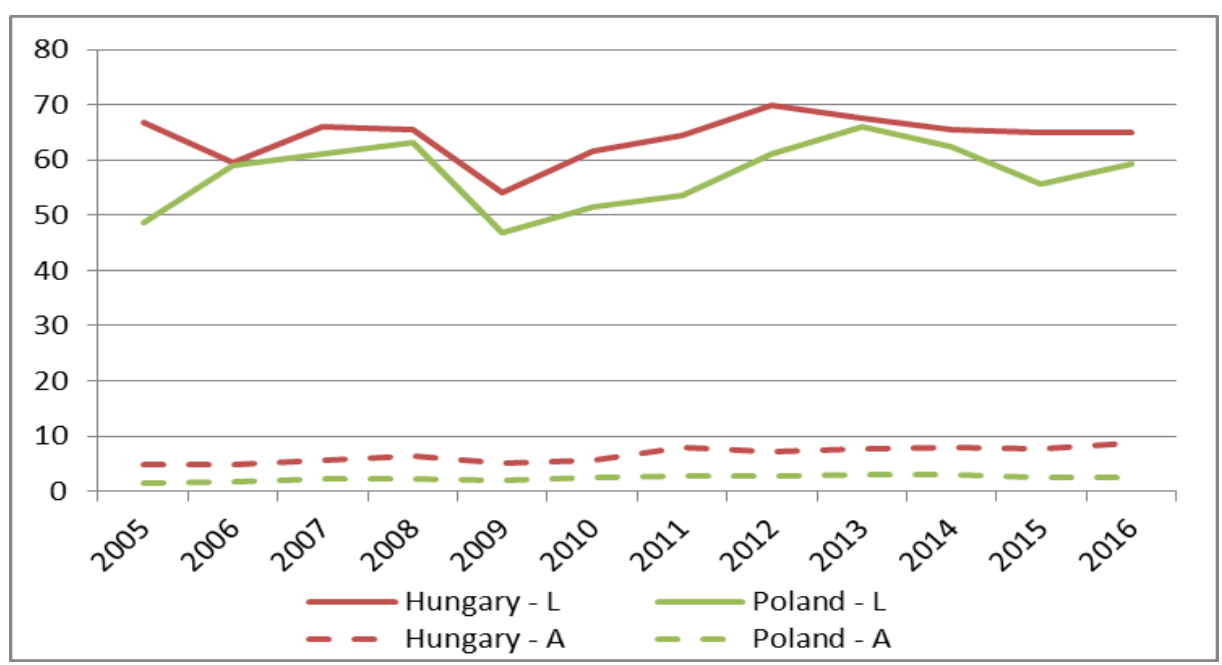

Figure 3: Comparing of work productivity in $L$ and $A$ sectors in Hungary and Poland 
Through comparing of both mentioned sectors development in whole analyzed period there is obvious the work productivity was higher in Hungary in both sectors, which is confirmed by fact that total work productivity for all NACE sectors was highest in Hungary, in comparing with Poland. Specifically average work productivity during whole period 2005-2016 in all sectors had value 11.29 EUR per hour worked in Hungary and 9.98 EUR per hour worked in Poland. Average values in low production sector A were as follows: Hungary 6.62 EUR per hour worked and only 2.82 EUR per hour worked in Poland. On the other hand, both countries achieved in high production sector of economy following average values: Poland 57.33 EUR per hour worked and Hungary yet 64.29 EUR per hour worked. According Figure 3 we can see that work productivity development in those two chosen sectors had similar character for both countries. Also after slight decrease of work productivity in L-sector in Hungary in 2006 there was basically recorded growth of work productivity to 2008 and it was repeated after the crisis from 2010 . Sector A is connected with physical human working source. Therefore, we see both countries Hungary and Poland as space for installment of still new technologies to production or alternative production methods, which could help to increase work productivity mainly in the mentioned sector.

\subsection{Comparing of employment according the gender}

In employment development during whole analyzed period men had always higher measure of employment then women, concretely measure of employment for men moved over $75 \%$ and for women over $60 \%$. In last four years Slovakia recorded increase of employment, which reflected also on partial growth of men and women employment. Total employment in Slovakia moved together around $70 \%$ level of employment (see Figure 4).

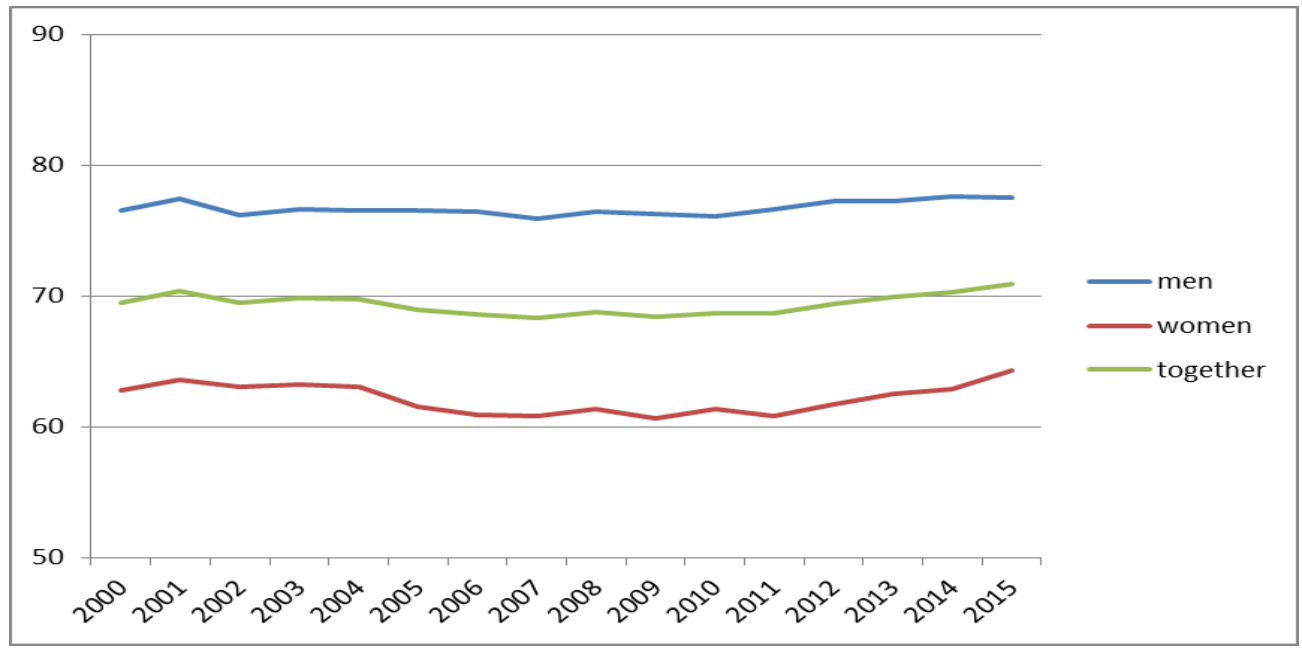

Figure 4: Development of employment in Slovakia

Source: own processing according database Eurostat 
Following Table 4 summarizes indexes of description statistics of employment. During the whole analyzed period average annual employment in Slovakia was at the level $69,36 \%$, which presents in absolute expression 2267000 employed persons.

Table 4: Indexes from description statistics for employment in Slovakia at the level NUTS1 during 2000-2015

\begin{tabular}{|l|c|c|c|}
\hline & Men & Women & Sum \\
\hline Average $(\overline{\boldsymbol{X}})$ & 78.031 & 62.856 & 69.363 \\
\hline Average deviation $(\overline{\boldsymbol{d}})$ & 1.531 & 1.331 & 0.642 \\
\hline Dispersion $\left(\boldsymbol{s}^{2}\right)$ & 3.167 & 2.776 & 0.562 \\
\hline Standard deviation $(\boldsymbol{s})$ & 1.78 & 1.67 & 0.75 \\
\hline Variation range $(\boldsymbol{R})$ & 5.5 & 5.7 & 2.6 \\
\hline Variation coefficient $(\boldsymbol{V})$ & 2.281 & 2.651 & 1.081 \\
\hline
\end{tabular}

Source: own processing according database Eurostat

Average deviation and average were higher for men, which confirm higher interest of job. According values of standard deviation we can say to which measure individual measured values of employment exist around medium values, while applicable the lower is standard deviation, the closer are measured values around average value. Women had lower deviation from average values $(1.67 \%)$ comparing with men $(1.78 \%)$, therefore dispersion was lower for women employment then for men employment. On the other hand, index variation range was higher for women as well as variation coefficient, which means variability of annual values for women was higher than for men.

Due to the comparing we analyzed gender segregation at the job market in Czech Republic during the same time period, from which there is obvious higher total employment in Czech Republic together during 2000-2015. Similar development of employment for both genders in comparing with total development is illustrated by Figure 5. As for the women, there is more visible decrease of employment during crisis years 2007-2009, when Slovakia had moderate amplitude. In Czech Republic there is more considerable growth of employment in last year's mainly for men. 


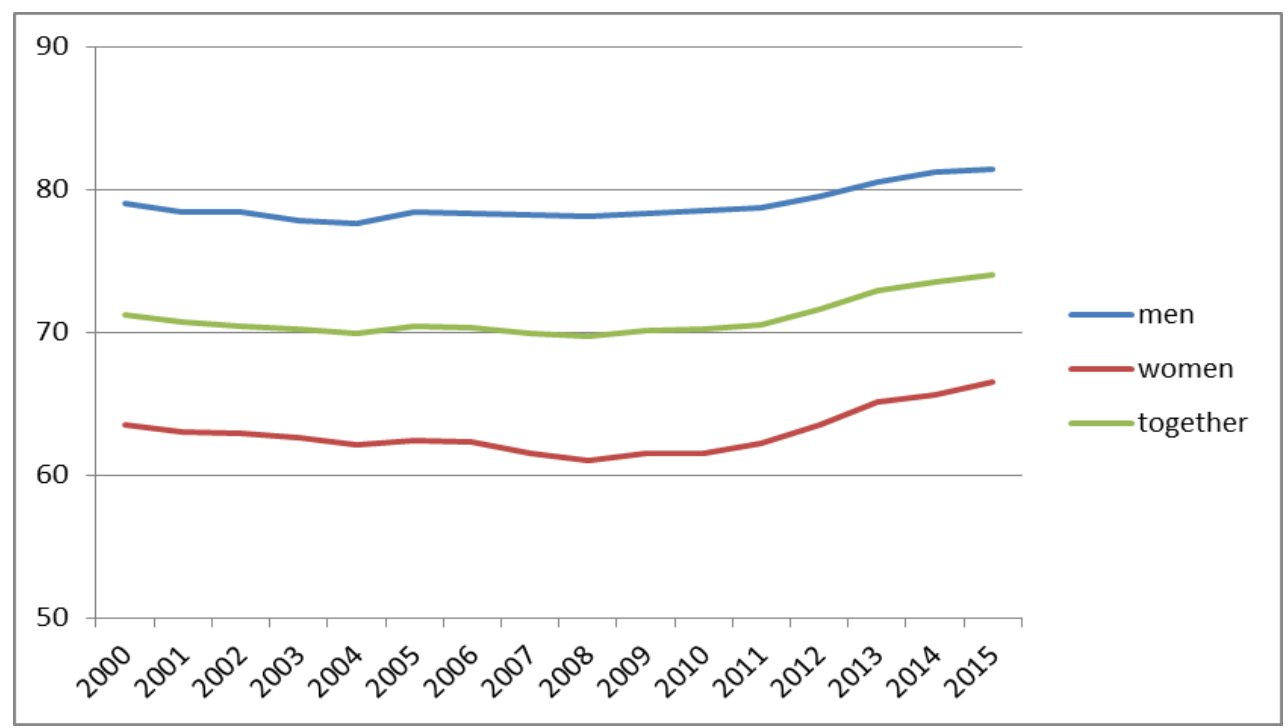

Figure 5: Development of employment in Czech Republic

Source: own processing according Eurostat

In Czech Republic in analyzed period average annual employment was higher than in Slovakia, concretely it achieved average value $70.97 \%$, which presents absolute 4777000 employed persons. Average deviation for women was at the level 0.768 , which confirms growth of interest for women work. Men with $0.845 \%$ have lower deviation from average values than women with $0.952 \%$, but dispersion is for men employment in Czech Republic lower. Also variation range and variation coefficient is the same, so we can say there is more interest for women work in Czech job market. Mentioned data are given in Table 5.

Table 5: Indexes of description statistics for employment in Czech Republic at the level NUTS1 during 2000-2015

\begin{tabular}{|l|c|c|c|}
\hline & Men & Women & Sum \\
\hline Average $(\overline{\boldsymbol{X}})$ & 77.55 & 62.206 & 70.969 \\
\hline Average deviation $(\overline{\boldsymbol{d}})$ & 0.706 & 0.768 & 1.045 \\
\hline Dispersion $\left(\boldsymbol{s}^{2}\right)$ & 0.714 & 0.907 & 1.687 \\
\hline Standard deviation $(\boldsymbol{s})$ & 0.845 & 0.952 & 1.299 \\
\hline Variation range $(\boldsymbol{R})$ & 2.9 & 3.7 & 4.3 \\
\hline Variation coefficient $(\boldsymbol{V})$ & 1.09 & 1.53 & 1.83 \\
\hline
\end{tabular}

Source: own processing according Eurostat

There is necessary to consider Czech Republic has two times more inhabitants than Slovakia, which connects also with two times higher number of employed. According mentioned statistics we found mainly in Slovakia in analyzed period employment had been increasing in every year for women more than in Czech Republic, according which 
we can state Slovakia is in the situation, when not giving emphasize only to the men work, but also increasing annually number of employed women. In spite of various mistaken ideas what gender makes the work better, there can rise still mistaken ideas about existence of typically women or typically men professions and it can lead to the differences in men or women employment, or differences in evaluation of their job. Different wages evaluation can decrease motivation to improve and achieve better performance, to try achieve career growth, or to cause resentment of women to work and by this way decreasing women employment. To avoid decreasing of gender segregation in area of rewarding could be done for example by placing of employees in the company instead of the name under the code that does not define gender and by this way to provide during rewarding more direct emphasize to single performance of the employee, which could result from his productivity.

In Slovakia gender equality is provided by following legal framework: anti-discrimination law, Labor Code, reservation of basic jobs and liberties and Constitution of Slovak Republic (Pietruchová \& Magurová, 2011) Also document National strategy of employment in Slovakia to 2020 consists of goals of gender equality at the job market. From the long term view men present more than $55 \%$ of total employed number with most abundant age category of working persons in age between 30-39 years. For women this age category is between 35-49 years. Single gender equality is grounded also in basic EU principles and its part of European social policy (Dudová, 2011).

\section{Discussion}

In present time to raise work productivity cannot be done without structural reform (Cai \& Zhang, 2017). This requires more fundamental institutional change, which depends on clear visions of the framework for a modern market economy, encompassing the rule of law and stronger property rights.

Firm's productivity can be improved by implementing work-life balance (WLB), especially in SMEs (Adame-Sánchez et al., 2016). Nevertheless, the firm's decision to implement WLB policies depends on how the firm perceives the benefits of such policies.

Manufacturing and Production Industries provide the most diligent profession. They do not merely participate in possessing a fundamental responsibility, for providing a huge extent of work opportunity but also assist in industrialization (Sri Ranjini, 2017).

Schein and Haruvi (2017) reviewed various studies that argue that working an extreme number of hours has little benefit to productivity. Rather workers in wealthier countries work on average fewer hours than workers in poorer countries and that a reduction in the average weekly hours worked in a country does not cause decline of DGP of the country.

Similar study had been done by Cette et al. (2011), testing whether the elasticity of hourly productivity to working time is negative and decreasing with working time itself. It could 
indicate a fatigue effect that increases with working time and the productivity per hour to working time would be negative and decreases with working time.

In area of employment the state has a very important role (Koch, 2016): the state as employer, redistributor, and arbiter, and as a shaper of employment relations and welfare. Government should aim to integrate employment and wages into the growth system both in the short and long run through targeting variable such as interest rate (Asaleye et al., 2017).

Different roles and models of behavior of men and women can be seen in any type of the society, mainly from demographic, historic or geographic point of view (Lindsey, 2015). In the society there is formed role of women and men, influenced by various factors, expectations, norms or prejudices and pressure of the society. Gender segregation at the job market presents therefore result of social formulas of different role perceiving for both genders (Barošová, 2004). Gender segregation at the job market can be directly seen also with certain types of professions, which are perceived as stereotype for men, or only for women. According Šipikalová (2013) gender segregation is divided to vertical and horizontal segregation. Vertical segregation is visible at the same position, but at different levels of employment and significance of working position only in one gender, regularly at men workers, which achieve also higher position with higher probability in the same group of professions. On the other hand, at the horizontal gender segregation at the job market we speak about various concentrations of men and women that incline to the different type of professions, when the reason could be tendency of both genders to work at different working positions with different level of rewarding.

In the frame of gender segregation at the job market there are professions, in which mainly women dominate (for example area of accommodation and catering, financial and insurance services, health care, education, public administration, etc.) and professions, in which mainly men dominate (for example professions, characteristic by physical power, stronger mathematical and logical thinking, higher possibilities of career growth and high responsibility). Researches show also differences in employment of men and women from the view of the wages. Differences in men and women rewarding reach yet $23 \%$ in favor of men and it can be justified also by women preference to work for a short term, to have more often breaks in working process due to the maternity leave or changes of profession, which could slow down their career growth and by this way also length of the practice of women is regularly shorter than practice of men (Polonyová \& Stanek, 2011).

\section{Conclusion}

The research proved development of work productivity has an increasing trend. Little decrease of work productivity had been recorded due to the global financial crisis that influenced slowdown or decrease of economic growth as well as work productivity. The results show the worst work productivity is achieved in economic activities that are based on physical human sources and generally achieve low wage evaluation of the employees, 
which could be also one of the reasons for low productivity. On the other hand, sectors with high work productivity, mainly financial and information sector, dispose with high technological equipment that help the workers in production process and wages are in these sectors generally higher. Mainly those two aspects can be main components for achievement of high work productivity.

In employment development during whole analyzed period men had always higher measure of employment then women. In last four years there was recorded increase of employment, which reflected also on partial growth of men and women employment. In spite of various mistaken ideas what gender makes the work better, there can rise still mistaken ideas about existence of typically women or typically men professions and it can lead to the differences in men or women employment, or differences in evaluation of their job.

\section{Acknowledgement}

Contribution is part of the project VEGA No. 1/0310/16 - Identification of Factors Determining Bankruptcy of Companies in Conditions of Chosen Industrial Sectors and VEGA No. 1/0651/18 - Research of institutional environment influence to the corporate social responsibility, consumer's satisfaction and performance of the company.

\section{References}

Aw, B. Y., \& Hwang, A. R. 1995. Productivity and the export market: A firm-level analysis. Journal of Development Economics, 47(2), 313-332. DOI: 10.1016/0304-3878(94)00062-H

Adame-Sánchez, C., González-Cruz, T. F., \& Martínez-Fuentes, C. 2016. Do firms implement work-life balance policies to benefit their workers or themselves? Journal of Business Research, 69(11), 55195523. DOI: 10.1016/j.jbusres.2016.04.164

Arnold, J. M., \& Hussinger, K. 2005. Export behavior and firm productivity in German manufacturing: A firmlevel analysis. Review of World Economics, 141(2), 219-243. DOI: 10.1007/s10290-005-0026-8

Asaleye, A. J., Olurinola, I. O., Oloni, E. F., \& Ogunjobi, O. 2017. Productivity growth, wages and employment Nexus: Evidence from Nigeria. Journal of Applied Economic Sciences, 12(5), 13621376.

Baek, H. Y., \& Neymotin, F. 2016. Young startup firm exports and productive efficiency. Applied Economics Letters, 23(15), 1088-1092. DOI: 10.1080/13504851.2015.1136389

Barošová, M. 2004. Application of principle of equal rewarding in chosen EU countries (in Slovak). Bratislava: Stredisko pre štúdium práce a rodiny. [online] www.ceit.sk/IVPR/images/IVPR/pdf/2004/barosova/Uplat_principu_04.pdf

Bernard, A. B., Eaton, J., Jensen, J. B., \& Kortum, S. 2003. Plants and productivity in international trade. American Economic Review, 93(4), 1268-1290. DOI: 10.1257/000282803769206296 
Cai, F., \& Zhang, X. 2017. Structural reform for economic growth. Australian Economic Review, 50(4), 450459. DOI: $10.1111 / 1467-8462.12248$

Camps, J., Luna-Arocas, R. 2009. High involvement work practices and firm performance. International Journal of Human Resource Management, 20(5), 1056-1077. DOI: 10.1080/09585190902850273

Cette, G., Chang, S., \& Konte, M. 2011. The decreasing returns on working time: An empirical analysis on panel country data. Applied Economics Letters, 18(17), 1677-1682.

Delgado, M. A., Farinas, J. C., \& Ruano, S. 2002. Firm productivity and export markets: A non-parametric approach. Journal of International Economics, 57(2), 397-422. DOI: 10.1016/S0022-1996(01)001544

Dhingra, S., \& Morrow, J. 2017. Efficiency in large markets with firm heterogeneity. Research in Economics, 71(4), 718-728.

Donnellan, T., \& Hanrahan, K. 2017. Value added and employment growth in EU primary agriculture and food processing. EuroChoices, 16(3), 4-9. DOI: 10.1111/1746-692X.12174

Dudová, I. 2011. European social systems (in Slovak). Bratislava: Ekonóm.

Eurostat. 2017. Employment by age, professional status and NUTS. [online]. http://ec.europa.eu/eurostat/data/database?node_code=lfst_r_lfe2estat

Gust, C., \& Marquez, J. 2004. International comparisons of productivity growth: The role of information technology and regulatory practices. Labour Economics, 11(1), 33-58. DOI: 10.1016/S09275371(03)00055-1

Hakelová, M., Csikósová, A., \& Antošová, M. 2013. The model of manpower management influence on mining business effectiveness. Acta Montanistica Slovaca, 18(2), 85-90.

Harris, R., \& Moffat, J. 2016. The UK productivity puzzle, 2008-2012: Evidence using plant-level estimates of total factor productivity. Oxford Economic Papers, 69(3), 529-549. DOI: 10.1093/oep/afw057

Koch, M. 2016. The role of the state in employment and welfare regulation: Sweden in European context. International Review of Social History, 61(24), 243-262. DOI: 10.1017/S0020859016000419

Kolveková, G., \& Palaščáková, D. 2017. Calculation of localization quotient for employment in cities of Slovakia-prešov and košice. Principles of changes in employment of the productive people. Journal of Applied Economic Sciences, 12(2), 604-614.

Kornelakis, A., Veliziotis, M., \& Voskeritsian, H. 2017. How can competitiveness be achieved in post-crisis Europe: Deregulating employment relations or enhancing high performance work practices? International Journal of Human Resource Management, 28(21), 2957-2976. DOI: 10.1080/09585192.2016.1233445

Lindsey, L. L. 2015. Gender roles: A sociological perspective. Routledge.

Lisý, J. et al. 2016. Economics (in slovak). Bratislava: Wolters Kluwer. 
Lukáč, J., Lukáč, J., \& Rozkošová, A. 2017. Financial and economic performance in context of SMEs (in Slovak). Košice: TypoPress.

Muller, P. et al. 2017. Annual report on European SMEs 2016/2017. Focus on self-employment. London: Economics Innova. [online]. https://ec.europa.eu/docsroom/ documents/26563/attachments/1/translations/en/renditions/native

Oosterhaven, J., \& Broersma, L. 2007. Sector structure and cluster economies: A decomposition of regional labor productivity. Regional Studies, 41(5), 639-659. DOI: 10.1080/00343400601120320

Onkelinx, J., Manolova, T. S., \& Edelman, L. F. 2016. The human factor: Investments in employee human capital, productivity, and SME internationalization. Journal of International Management, 22(4), 351364. DOI: 10.1016/j.intman.2016.05.002

Petrashchak, O., Kolosinskyi, I., Kolosinska, M., \& Marych, M. 2017. Youth satisfaction with the employment: A survey. Economic Annals-XXI, 166(7-8), 96-99. DOI: 10.21003/ea.V166-19

Pietruchová, O., \& Magurová, Z. 2011. Methodologic study for legislative amendments following for gender equality in chosen EU countries and application in legislative order of Slovakia (in Slovak). Bratislava: Centrum vzdelávania Ministerstva práce, sociálnych vecí a rodiny. [on-line] www.gender.gov.sk/wpcontent/uploads/ 2012/06/studia final august2011.pdf

Schein, A., \& Haruvi, N. 2017. The relationship between the average workweek lenght and per capita gross domestic product. International Studies of Management and Organization, 47(4), 311-323.

Sri Ranjini, S. 2017. An examination of the essential aspects, in execution of enterprise resource planning in manufacturing and production industries. International Journal of Mechanical and Production Engineering Research and Development, 7(6), 395-402. DOI: 10.24247/ijmperddec201744

Stanek, V. et al. 2011. Social policy: Theory and Practice (in Slovak). Bratislava: Sprint.

Šipikalová, S. 2013. Global social inequality in EU context (in Slovak). Bratislava: Ekonóm.

Tkáč, M. 2001. Statistical management of quality (in Slovak). Bratislava: Ekonóm. 